\title{
LOCAL WISDOM-ORIENTED PROBLEM-SOLVING LEARNING MODEL TO IMPROVE MATHEMATICAL PROBLEM-SOLVING ABILITY
}

\author{
Ni Nyoman Parwati $(\mathbb{D}$, I Gusti Putu Sudiarta $(\mathbb{D}$, I Made Mariawan $\mathbb{D}$, I Wayan Widiana $(\mathbb{D}$ \\ Universitas Pendidikan Ganesha (Indonesia) \\ nyoman.parwati@undiksha.ac.id,.gussudiarta@undiksha.ac.id,made.mariawan@undiksha.ac.id, \\ wayan_widiana@yahoo.co.id
}

Received February 2018

Accepted May 2018

\section{Abstract}

The aim of this study was to describe and to test the effect of learning model (problem solving learning model oriented toward Balinese local wisdom (PSBLW) Vs Direct Instruction Model (DI)) and type of mathematics problems (open and closed problems) on the ability to solve mathematics problem of the fifth-grade students of elementary in Singaraja Bali. This quasi-experimental research used non-equivalent control group design with pretest and posttest. The data were analyzed with factorial $2 \times 2$ analysis of covariance (Anacova). The sample consisted of the fifth-grade students of Elementary School with the total of 152 students spread into 4 classes. The sample was selected by cluster random sampling. The data were collected using mathematics problem solving ability test at the $5 \%$ significance level $(\alpha=0.05)$. The statistical analysis was done with the aid of SPSS 16.0 for Windows. The results showed that (1) the ability, may to solve mathematics problems of the students who learned through PSBLW is higher than those who learned through direct instructional model; (2) the students' ability to solve problems facilitated with open mathematics problems was higher than that with closed mathematics problems; and (3) there is effect of interaction between learning model and problem type on problem solving ability. The conclusion is local wisdom-oriented problem-solving learning model effective to improve mathematical problem-solving ability.

Keywords - Problem-solving learning model, Local wisdom, Types of mathematical problems, Ability to solve mathematics problems.

\section{Introduction}

Mathematics is which underlies modern technology development, has an important role in various disciplines and develop human cognitive ability since early years (Parwati, 2011). Mathematics needs to be given to all students starting from elementary school to provide them with logical, analytical, systematical, critical, and creative thinking ability, the ability to solve various problems in life, and the ability to cooperate. These competencies are needed to enable the students to have the ability to obtain, to manage and use information to survive in the always changing, unsure, and competitive condition (Rokhman, Hum, Syaifudin, \& Yuliati, 2014). Mathematics teaching given at school is naturally oriented toward the attainment of the ability. Mathematics teaching at school is also oriented toward developing the ability to develop the ability to use symbols, tables, diagrams, or other media. In addition, mathematics teaching can also train the development of students' positive characters (Rokhman et al., 2014; Parwati, Sudiarta \& Mariawan, 2014). 
The objective of mathematics education at elementary school according to the standard as stated by National Council of Teachers of Mathematics (NCTM) is to enable the students to understand mathematics concepts and to apply them in solving everyday problems (Bossé, Lee, Swinson \& Faulconer, 2010). The objectives of mathematics education at elementary school according to Kemendiknas (2010) are numerous, other things, are for the students to have the ability to understand concepts and applying them in solving problems, and to have a persistent attitude and self confidence in solving problems. Furthermore, it is said that the results of learning mathematics at elementary school consist of: (1) concepts understanding; (2) reasoning and communication, and (3) problem solving ability. The national educational system act among other things states that the objectives of the national education are to develop the potential of the students to become human beings who have faith and devotion to God, good behavior, healthy, knowledgeable, capable, creative, independent, and become democratic citizens and are responsible.

The act signals that the objective of education actually emphasizes the process and product in harmonious way between intellectual development and spiritual development, without separating the two dichotomously. This development is the duty of all teachers of all subjects. Thus, all teachers are obliged to learn how to develop characters of the students to become optimal, in accordance with the objective of education.

Considering the focus and objective of mathematics education at elementary school, as has been explained previously, it seems that there are still many problems faced in an effort to achieve the objective and to implement mathematics teaching at elementary school. The problems of mathematics teaching at elementary school so far can be reviewed from some variables of teaching and one of which is the delivering strategy (Reigeluth \& Carr-Chellman, 2009). The delivering strategy is the component to conduct the teaching process. There are two things which become the focus here, that is, the way to deliver the contents of teaching to the students and to provide information and materials needed by the students to show their performances. The teaching delivery strategy used by elementary school teachers so far is still less innovative (Parwati et al., 2014; Jitendra, Petersen-Brown, Lein, Zaslofsky, Kunkel, Jung et al., 2015; Sharif \& Gisbert, 2015). In other words, most of the teachers mostly use direct instructional model.

Another problem so far in teaching mathematics at school is that the teachers have not given an emphasis on the students' positive character development. Mathematics teaching still focuses on the effort to develop intelect only, so that character development is neglected by the mathematics teachers. The ability to solve problems will be achieved optimally if it is balanced by the presence of positive characters in the students. Some character values which need to be possessed by the students in this case are honesty, perseverance, not easy to give up, democratic and able to work together (Freeman-Green, O'Brien, Wood \& Hitt, 2015; Rokhman et al., 2014).

The impact of teaching implementation so far is a still low ability of the students to solve mathematics problems. The nonachievement of the balance in learning outcome especially between cognitive and affective domains which should be achieved according to the objective of the national education. The survey done (Parwati et al., 2014) shows that in the implementation of mathematics teaching at elementary school, most of the teacher's still use drill method, which is less relevant to the teaching of problem solving which becomes the focus of mathematics teaching. Then it is also said that in mathematics teaching implementation there has not been an emphasis given on the students' positive character. In the mathematics teaching, the students are easy to give up when they face problem solving items. In the survey it was also found that the teachers have not found an effective way to teach problem solving so that this causes low ability to solve problems on the part of the students.

International scaled study results such as from PISA, TIMSS revealed Indonesian students' mathematics achievement is still at the lowest tenth, the 63th ranking from 69 countries (OECD, 2015). PISA problems are not only directed to the ability to apply concepts but are more largely to how the concepts can be applied in various situations and the students' ability to reason and argue on how the problems are solved. However, this problem does not only exist in Indonesia, the finding of Freeman-Green et al. (2015); 
Jitendra et al. (2015); Phonapichat, Wongwanich and Sujiva (2014) shows that the elementary school students' ability to solve mathematics problems is a problem which is experienced almost internationally.

One of the ways to overcome the low level ability of the students in solving mathematics problems is by selecting a suitable learning model which stresses problem solving activities (Sánchez-Martín, Álvarez-Gragera, Davila-Acedo, \& Mellado, 2017). In mathematics two types of problems are differentiated, that is, open and closed mathematics problems. An open mathematics problem according to Lin and Lien (2013); Intaros, Inprasitha and Srisawadi (2014), is a problem with many solutions. While a closed mathematics problem is a problem which is formulated clearly and only has one correct value. So far, the common problems presented in mathematics teaching activity are a closed/well-defined problem (Bahar \& June Maker, 2015; Parwati, 2011). In an effort to train students to solve mathematics problems, they need to be given exercises to solve open mathematics problems. This is in line with the perspective of Lin and Lien (2013) who say that there are some advantages of open mathematics problems, that is, the students are more active developing thinking skill with varied methods, the students have the opportunity to use knowledge more widely, the students can solve problems meaningfully with their own ways, and they give the students rational thinking experiences. The example of closed and open mathematics problems are presented in Table 1.

In solving mathematics problems there are some strategies which can be used as guide, one of them is stated by Polya (1957) which consists of 4 stages, that is, (1) understanding the problem; (2) devising a plan; (3) carrying out the plan, and (4) looking back.

The teaching materials used by the teachers in teaching mathematics so far have not included problem solving items, especially open mathematics problems. The types of problems given to the students in the teaching of mathematics so far have been or ill-defined problems. Considering some advantages of presenting open mathematics problems at elementary school, the students need to be involved in the teaching activity to use materials that contain problems, especially open problems.

\begin{tabular}{|c|c|c|}
\hline No. & Closed Mathematics Problem & Open MathematicsProblem \\
\hline & \multicolumn{2}{|c|}{ Topic: Least Common Multiple and Greatest Common Divisor } \\
\hline 1. & 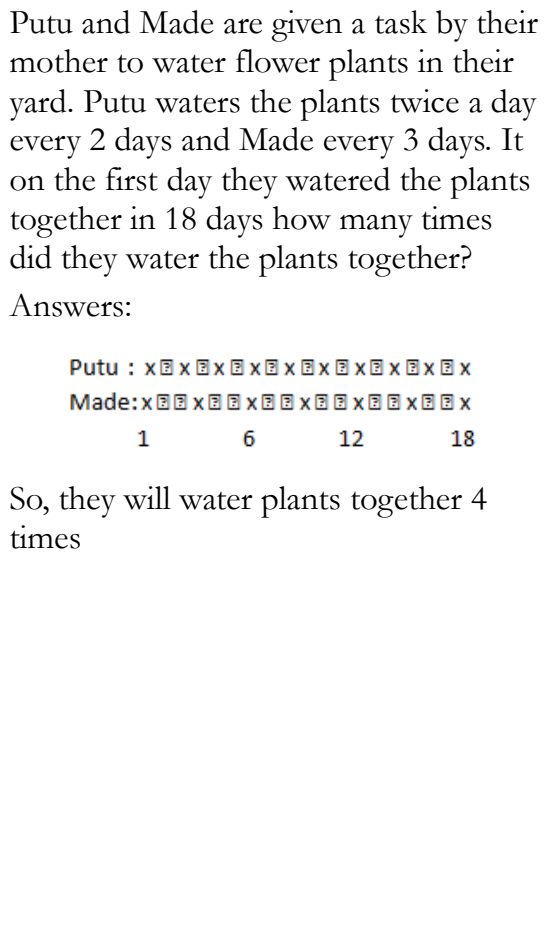 & 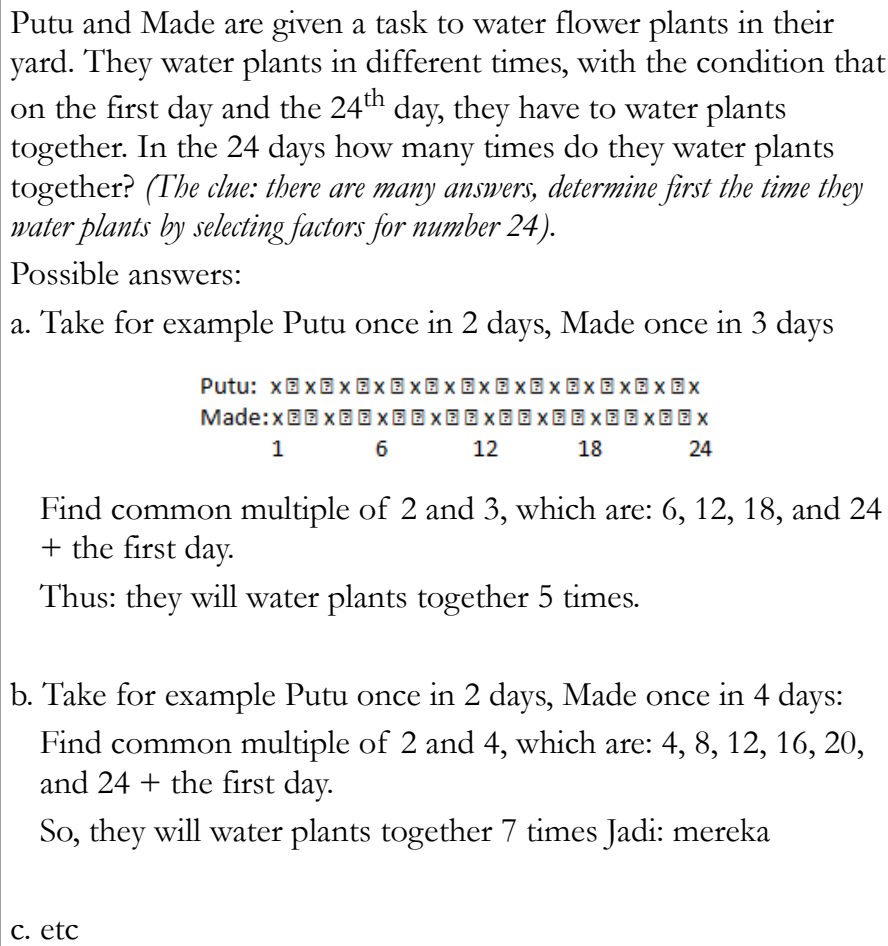 \\
\hline
\end{tabular}

Table 1. Comparison between Open Mathematics Problem and Closed Mathematics Problem 
The ability to solve problems is one of the nation's positive characters. Some opinions state that positive characters need to be developed in the students in the 21st, according to Rokhman et al. (2014); Almerico (2014) they are: (1) creative, ability to analyze and solve problems; (2) having an interest in long-life learning; (3) creative thinking; (4) being able to learn anything according to the demands of the era; (5) being able to become effective communicators; (6) being brave to take; (7) being able to work hard; (8) integrity: honest, self-discipline, responsibility, and (9) fully attentive, tolerant brave to take risks, and flexible. According to Kemendiknas there are 18 national characters which need to be developed in administering education at school. i.e., religious, honest, tolerant, hardworking creative, autonomous, democratic, curious, national spirit, love for the nation, respecting achievement, friendly/communicative, love for peace, like reading, take care with the environment, social concern, and being responsible (Kemendiknas, 2010). Considering values of positive characters which need to be built in the students, problem solving learning model is very potential in attaining the values.

Problem solving learning model is based on cognitive learning theory and constructivism which assume that children have innate curiosity and continuously understand the world around it and regards that class is a reflection of larger community and functions as a laboratory to learn solve concrete work real word problem (Arends, 2012). Another assumption is intellectual development will another assumption is that intellectual development will occur at the time individuals face an new and challenging experience and when they attempt to solve the problem which is caused by the experience (Krulik \& Rudnick, 1996). Problem solving learning model is different from that which uses direct instructional model. The direct instructional model follows the following steps: presenting an objective and a new material by the teacher, giving examples of problems and discussing them, and finally practice of solving problems which are generally of closed problem type.

The implementation of problem solving model in mathematics teaching gives a very great opportunity to develop the students' positive characters. This is done through an integration of local wisdom values in each step of activities which consist of: Read and Think, Explore and Plan, Select Strategies, Find Answers, Reflect and Extend (modified from Krulik \& Rudhick, 1996). Local wisdoms are the ways and practices developed by a group of people, which originated from their deep understanding of the local environment, formed from living in the place from generation to generation (Kun, 2013; Hariyadi, Fikri \& Fatahillah, 2016). Such knowledge has some important characteristics which make them different from other types of knowledge. Local wisdoms came from the people themselves, spread out widely non-formally, possessed collectively by the community in question, developed for some generations and easily adapted, as well as cultivated in the way of life of the community as a means to survive. Local wisdoms are related specifically to a particular culture and reflect the way of life of a particular community. Another opinion says that the truths that have become traditions or consistent in an area are called local wisdoms (Mungmachon, 2012).

Based on the opinions above, local wisdoms in this study are integration between sacred values and various values that exist in the community in which the local wisdoms are formed such as the advantage of a local culture in general terms. The implementation of problem solving learning model oriented toward local wisdoms was done by integrating local wisdom values in the students' book or students' worksheets to cultivate positive character values and as the "jargons" used to motivate the students to learn (Mungmachon, 2012). As an example, when the students would start a discussion to solve a problem given, they were motivated by using a slogan in the students' worksheet taken from Balinese local wisdom "yeh ngetel mekelo-kelo bisa molongin batu" (water drops can in a long time make a hole on a rock). The meaning contained in the message is'no matter how small is an effort, if it is done persistently in a long time will produce an amazing result. Another local wisdom is, for example, at the end of an exercise on a problem is stated "siat-siat wayange pamuputne pamundub dadi besik di gedogane" (like a war in a puppet shadow, at the end all puppets will unite in their storing place). The meaning is related to conflict management, although during a discussion there was a dispute because of differences of opinions, but all of it is a means to find a true conclusion. 
In this study a comparative test was done between learning models, types of problem, and interaction between learning model and type of problem as well as interaction between learning model and type of problem with the ability to solve mathematics problems in the fifth-grade students in Singaraja city, Bali. The learning model tested was problem solving learning model with an orientation toward Bali local wisdoms compared to direct model which is generally selected by the teachers. The type of problem tested was open mathematics problem compared to closed mathematics problem which is commonly given at elementary school.

\section{Research Method}

This study used quasy experimental design of non-equivalent control group design with pretest and posttest. The independent variable in this study was learning model which consisted of two dimensions, that is, problem solving learning model oriented toward Balinese local wisdom and direct instruction model. The second independent variable was a type of mathematical problem consisted of two dimensions, that is, open and closed mathematical problems. The dependent variable was the students' ability to solve mathematics problems. As a covariate was a pretest score of the students' ability to solve mathematics problems. Based on the types of variables studied, the testing of hypotheses in this study was done by using factorial $2 \times 2$ Ancova (Tuckman, 1999).

The population of elementary schools is 46 , consisting of 43 public elementary schools and 3 private elementary schools. Out of the 46 schools, four classes were selected as sample by cluster random sampling or multistage procedure, which represents classes with equivalent academic achievement. The subjects were the fifth grades of elementary schools are 152 students that were spread in 4 classes. Each of the four classes selected was treated differently, i.e.: the problem-solving learning model with open mathematics problems (PSBLW-OP), the problem-solving learning model with closed mathematics problems (PSB-CP), the direct instructional model with open mathematics problem (DI-OP), and the direct instructional model with closed mathematics problems (DI-CP).

The instrument for data collection was a test of ability to solve mathematics problems, for pretest with alpha Cronbach coefficient at 0.90 and posttest with alpha Cronbach coefficient at 0.94. The null hypotheses tested in this study are as follows. (1) There is no significant difference in problem solving ability between the group of students taught by using problem solving learning model oriented toward Balinese local wisdom and the group taught by using direct instruction; (2) There is no significant difference in problem solving ability between the group of students given open problem type and the group given closed problem type; (3) There is no effect of interaction between learning model and problem type on problem solving ability. A null hypothesis testing was done at $5 \%$ level of significance or $\alpha=0.05$. All of statistical analyses were done by using SPSS 16.0 for Windows software.

\section{Results and Discussion}

\subsection{Research Results}

\subsubsection{The Result of the Pretest of the Ability to Solve Problems}

Briefly, the result of the pretest of the ability to solve problems is described in table 2. Pretest is given to all four groups of students using the same test. This is done to determine the equality of the initial ability of each group of students. In table 2 it is shown that the mean score of the pretest in Treatment with PSBLW-OP model is 54.17 with standard deviation of 9.72 and PSBLW-CP model is 52.79 with standard deviation of 9.42. In the group of teaching with DI-OP model the mean score of pretest is 54.12 with standard deviation of 9.01 and DI-CP model is 52.06 with standard deviation of 8.60 . Viewed from the two groups of learning models, it can be seen that the mean score of pretest for the two groups is almost the same and with a small enough standard deviation. Based on the results, it is seen that there is a slight difference in mean score, that is, the students given open mathematics problems have a higher mean score than those given closed mathematics problems. 


\begin{tabular}{|c|c|r|r|r|}
\hline MODEL & PROBLEM & \multicolumn{1}{|c|}{ Mean } & Std. Deviation & \multicolumn{1}{|c|}{ N } \\
\hline \multirow{3}{*}{ PSBLW } & OPEN (OP) & 54.17 & 9.72 & 41 \\
\cline { 2 - 5 } & CLOSED (CP) & 52.79 & 9.42 & 42 \\
\cline { 2 - 5 } & Total & & & 83 \\
\hline \multirow{3}{*}{ DI } & OP & 54.12 & 9.01 & 34 \\
\cline { 2 - 5 } & CP & 52.06 & 8.60 & 35 \\
\cline { 2 - 5 } & Total & & & 69 \\
\hline \multicolumn{2}{|c|}{ Total (PSBLW and DI): } & & & 152 \\
\hline
\end{tabular}

Table 2. Results of the Pre-test of the ability to Solve Problems in Each Group of Treatment

\subsubsection{Result of Posttest of the Ability to Solve Problems}

The description of the posttest ability to solve problems, presented in Table 3.

\begin{tabular}{|c|c|r|r|r|}
\hline MODEL & PROBLEM & \multicolumn{1}{|c|}{ Mean } & Std. Deviation & \multicolumn{1}{|c|}{ N } \\
\hline \multirow{3}{*}{ PSBLW } & OP & 84.10 & 4.16 & 41 \\
\cline { 2 - 5 } & CP & 72.10 & 3.59 & 42 \\
\cline { 2 - 5 } & Total & & & 83 \\
\hline \multirow{3}{*}{ DI } & OP & 74.91 & 3.40 & 34 \\
\cline { 2 - 5 } & CP & 60.63 & 4.82 & 35 \\
\cline { 2 - 5 } & Total & & & 69 \\
\hline \multicolumn{2}{|c|}{ Total (PSBLW and DI): } & & & 152 \\
\hline
\end{tabular}

Table 3. Results of the Posttest of the ability to Solve Problems in Each Group of Treatment

In Table 3 it is shown that the mean score of posttest in the treatment group with PSBLW-OP model is 84.10 with standard deviation of 4.16 and PSBLW-CP model is 72.10 with standard deviation of 3.59 . In the group of teaching with DI-OP model the mean score of posttest is 74.91 with standard deviation of 3.40 and DI-CP model is 60.63 with standard deviation of 4.82. Based on this, the average students' problem-solving abilities that follow the PSBLW learning model and DI model are 78.10 and 67.77 respectively. Other than that, viewed from the treatment group of students who learned through open mathematics problems $(\mathrm{OP})$ with the students who learned through closed mathematics problems $(\mathrm{CP})$, it was found that the mean scores of problem-solving abilities are: 79.51 and 66.37 respectively.

\subsubsection{Testing of Assumption}

The result of Kolmogorov-Smirnov Test of Normality of the posttest scores of problem-solving ability shows that sig. for all groups of treatments are greater than 0.05 , that is, 0.064 and 0.75 for the group of PSBLW and DI respectively; 0.200 and 0.095 for the group with open mathematics problems and closed mathematics problems respectively. Based on the results, it means that the scores of problem-solving ability for all groups have a normal distribution.

Variance homogeneity testing was done by using Levene's Test and it was found that the sig. value is 0.312 $>0.05$. This result means that the variance of the data of the inter group problem solving ability has a normal distribution. This means the four groups of samples have the same variance, so the requirements of the Anacova test have been fulfilled.

\subsubsection{Testing of Research Hypotheses}

Anacova test was used to see the difference in posttest mean scores in problem solving ability in the treatment groups. The result of Anacova testing is presented in Table 4. 


\begin{tabular}{|c|r|r|r|r|r|}
\hline Source & \multicolumn{1}{|c|}{ Type III Sum of Squares } & \multicolumn{1}{c|}{ df } & \multicolumn{1}{c|}{ Mean Square } & \multicolumn{1}{c|}{ F } & Sig. \\
\hline Corrected Model & $12625.964(\mathrm{a})$ & 8 & 1578.246 & 720.500 & .000 \\
\hline Intercept & 16512.808 & 1 & 16512.808 & 7538.423 & .000 \\
\hline PRETEST & 505.379 & 1 & 505.379 & 230.715 & .000 \\
\hline MODEL & 3835.290 & 1 & 3835.290 & 1750.885 & .000 \\
\hline PROBLEM & 6054.128 & 1 & 6054.128 & 2763.829 & .000 \\
\hline MODEL $*$ PROBLEM & 26.832 & 1 & 26.832 & 12.249 & .001 \\
\hline Error & 313.239 & 143 & 2.190 & & \\
\hline Total & 830117.000 & 152 & & & \\
\hline Corrected Total & 12939.204 & 151 & & & \\
\hline
\end{tabular}

Table 4. The Result of Two-way Anacova test for the Posttest of Problem Solving Ability

In Table 4 it is shown that, the Value of Corrected Model (sig.) is $0.000<0.05$ and the value of intercept (sig.) is $0.000<0.05$ can be interpreted; the learning model and the type of problem are influence and contribute significantly to the students' mathematical problem-solving abilities.

The first null hypothesis tested is "There is no significant difference in problem solving ability between the group of students taught by using problem solving learning model oriented toward Balinese local wisdom and the group taught by using direct instruction". The result of testing shows that sig. value of the learning model variable is 0.00 , smaller than 0.05 . This means that the null hypothesis is rejected or there is a significant difference in problem solving ability between the group of students taught by using problem solving model oriented toward Balinese local wisdom and the one which uses direct instruction model.

The second null hypothesis tested is "There is no significant difference in problem solving ability between the group of students given open problem type and the group given closed problem type". The result of testing shows that sig. value of the variable of problem type $=0.00$, smaller than 0.05 . This means the null hypothesis is rejected or there is a significant difference in problem solving ability between the group of students given open problems and the group given closed problems.

The third null hypothesis tested is "There is no effect of interaction between learning model and problem type on problem solving ability". The result of testing shows that sig. value of the variable of the effect of interaction between learning model and type of problem on problem solving ability is 0.00 , smaller than 0.05. This means that the null hypothesis is rejected or there is an effect of interaction between learning model and type of problem on problem solving ability. The pattern of interaction which occurs shows that the group of students given open mathematics problems is better than the group of students given closed mathematics problems for the two learning models (problem solving and direct instruction) and students who follow the learning with PSBLW learning model gain better problem-solving abilities from students following the DI learning model, for both types of problems (open and close problems).

\subsubsection{Post-Hoc Test}

In Table 5, the post-hoc test using the Scheffe test, obtained the results of multiple comparisons mean for the four treatment groups (PSBLW-OP, PSBLW-CP, DI-OP, and DI-CP) had significant differences in problem solving ability. The biggest mean difference is for the PSBLW-OP model with DI-CP (see Table 3). 


\begin{tabular}{|c|c|c|c|c|c|c|c|}
\hline & \multirow[b]{2}{*}{ (I) MODEL } & \multirow[b]{2}{*}{ (J) MODEL } & \multirow{2}{*}{$\begin{array}{c}\text { Mean Difference } \\
\text { (I-J) }\end{array}$} & \multirow{2}{*}{$\begin{array}{l}\text { Std. } \\
\text { Error }\end{array}$} & \multirow[b]{2}{*}{ Sig. } & \multicolumn{2}{|c|}{ 95\% Confidence Interval } \\
\hline & & & & & & Lower Bound & Upper Bound \\
\hline \multirow{12}{*}{ Scheffe } & \multirow{3}{*}{ PSBLW-OP } & PSBLW-CP & $12.00^{*}$ & .882 & .000 & 9.51 & 14.50 \\
\hline & & DI-OP & $9.19^{*}$ & .932 & .000 & 6.55 & 11.82 \\
\hline & & DI-CP & $23.47^{*}$ & .925 & .000 & 20.85 & 26.08 \\
\hline & \multirow{3}{*}{ PSBLW-CP } & PSBLW-OP & $-12.00^{*}$ & .882 & .000 & -14.50 & -9.51 \\
\hline & & DI-OP & $-2.82^{*}$ & .927 & .030 & -5.44 & -.19 \\
\hline & & DI-CP & $11.47^{*}$ & .920 & .000 & 8.87 & 14.07 \\
\hline & \multirow{3}{*}{ DI-OP } & PSBLW-OP & $-9.19^{*}$ & .932 & .000 & -11.82 & -6.55 \\
\hline & & PSBLW-CP & $2.82^{*}$ & .927 & .030 & .19 & 5.44 \\
\hline & & DI-CP & $14.28^{*}$ & .968 & .000 & 11.55 & 17.02 \\
\hline & \multirow{3}{*}{ DI-CP } & PSBLW-OP & $-23.47^{*}$ & .925 & .000 & -26.08 & -20.85 \\
\hline & & PSBLW-CP & $-11.47^{*}$ & .920 & .000 & -14.07 & -8.87 \\
\hline & & DI-OP & $-14.28^{*}$ & .968 & .000 & -17.02 & -11.55 \\
\hline
\end{tabular}

Based on observed means.

The error term is Mean Square (Error) $=16.150$.

*. The mean difference is significant at the .05 level.

Table 5. Multiple Comparisons Mean (Dependent Variable: POSTTEST)

\subsection{Discussion}

The discussion here is focused on the finding of the study about the interaction between independent variables which affects the dependent variable. That is there is an effect of interaction between learning model and type of problem on problem solving ability. The effect of interaction between learning model and type of problem on problem solving ability indicates that there is a joint effect between learning model and type of problem in attaining problem solving ability. Explicitly, it can be explained that (1) the group of students who learned through open mathematics problems attained a higher problem solving ability in the two learning models that were implemented; (2) the group of students given closed mathematics problems is better in attaining problem solving ability through problem solving learning model than direct instruction model, and (3) the group of students given open mathematics problem type is slightly better than the group of students given closed mathematics problems in problem solving learning model implementation. According to Hair, Black, Babin, Anderson and Tatham (2006) the type of interaction like this is an ordinal interaction.

Based on the type of interaction which occurred, it can be assumed that the difference in problem solving ability between treatment groups with the implementation of different learning models is not only influenced by the superiority of one of the learning models. This is seen in the treatment group with open mathematics problems, who are always better in the attainment of problem solving ability in the two types of learning model. However, for the treatment group with closed mathematics problems, the students are better in the problem-solving learning model than in direct instruction model.

The interaction pattern which occurred indicates that the significance in the difference in problem solving ability between problem solving learning model and direct instruction is contributed more by the superiority of open mathematics problems than with closed mathematics problems given to the students. As a theoretical implication the following discussion is in order.

First, mathematics problem solving ability is largely determined by prior knowledge of the students. This study shows that the students' prior knowledge in mathematics problem solving gives a different effect on their ability in solving problems. The students with better prior knowledge tend to obtain better problem-solving ability too. As an implication, in conducting mathematics teaching in the classroom in the fifth grade in elementary school particularly, the teachers should not neglect prior knowledge of the 
students. If in teaching the teacher neglects the students' prior knowledge, then the mathematical concepts wrongly understood will continue to the next stage of learning. This can occur because the mathematic materials taught at school follows a spiral method. In other words, every time learning a new topic, it is related to the previous one. According (Yusnaeni, Corebima, Susilo \& Zubaidah, 2017) learning uses problem solving strategy has the potential to improve the student creative thinking.

Secondly, the effort to attain problem solving ability is more effective through the implementation of problem solving learning model oriented toward local wisdom (PSBLW). In the PSBLW model, the students are familiarized to do activities of learning through problem solving activities since the start of the lesson. (Laisema \& Wannapiroon, 2014) revealed that, problem solving learning were appropriate to develop creative thinking skill. The problem presented contextually or drawn from problems commonly met in daily life. To a similar effect (Parwati at al., 2014; Pornpimon, Wallapha \& Prayuth, 2014) in this study it was also found that the integration of local wisdom values rich with noble values, is very effective to be used to motivate the students to learn so that their positive characters can develop, their problem solving ability can be improved. The implementation of the lesson designed through discussion gives the opportunity for active learning process to occur. The communication occurs in multi directions, both among the students and between the students and the teacher. The lesson occurs meaningfully, since most of the concepts are discovered by the students themselves. According (Yusnaeni, Corebima,Susilo \& Zubaidah, 2017) learning uses problem solving strategy has the potential to empower student confident attitude. Besides that, (Tatar, Tüysüz, Tosun \& İlhan, 2016)found that, the learning methods (e.g. context, problem, project based learning) increasing the curiosity level of students.

Thirdly, the implementation of problem solving learning model facilitated with the discussion on the open mathematics problem type encourages the development of divergent thinking skill. In other words, training the students to develop the way of thinking from various points of view. This occurs when the students try to find various solutions to problems given. With the development of such thinking skill it is hoped that it will give an impact on the students who will be more prepared in facing various problems in life. According to (Bahar \& June Maker, 2015), mathematics problem solving trains the students to always give rationales to their work. This has an implication in the development of students' sense of responsibility which is needed very badly by the students when they enter social life.

\section{Conclusion and Suggestions}

The problem-solving learning model and the type of open mathematics problems are more effective for improving mathematics problem-solving abilities than the Direct Instructional model and the types of closed mathematics problems. Based on the findings it can be concluded that problem solving learning model be used in attaining a higher level in mathematics problem solving competence. The problems presented in the beginning of a lesson serve as motivator for the students to learn and they should be selected from the contexts familiar to the students from their daily life. Problems assigned to students are not just routine problems or closed problems, but also non-routine problems with open-ended problems. In an effort to develop students' positive characters, there is a need to integrate the community local wisdoms which are rich with noble values. Open mathematics problems are suggested to be applied to train students to solve problems creatively. To researchers who intend to do a further study related to the results of this study is suggested to do a study on the other aspects of learning achievement, for instance, the achievement in Bloom's taxonomy perspective.

\section{Declaration of Conflicting Interests}

The authors declared no potential conflicts of interest with respect to the research, authorship, and/or publication of this article.

\section{Funding}

The authors received no financial support for the research, authorship, and/or publication of this article. 


\section{References}

Almerico, G.M. (2014). Building character through literacy with children's literature. Research in Higher Education Journal, 26, 1-13.

Arends, R.I. (2012). Learning to Teach ninth edition. New York: McGraw-Hill Companies, Inc.

Bahar, A., \& June-Maker, C. (2015). Cognitive Backgrounds of Problem Solving: A Comparison of Open-ended vs. Closed Mathematics Problems. Eurasia Journal of Mathematics, Science and Technology Education, 11(6), 1531-1546. https://doi.org/10.12973/eurasia.2015.1410a

Bossé, M.J., Lee, T.D., Swinson, M., \& Faulconer, J. (2010). The NCTM Process Standards and the Five Es of Science: Connecting Math and Science. School Science and Mathematics, 110(5), 262-276.

https://doi.org/10.1111/j.1949-8594.2010.00033.x

Freeman-Green, S.M., O’Brien, C., Wood, C.L., \& Hitt, S.B. (2015). Effects of the SOLVE strategy on the mathematical problem solving skills of secondary students with learning disabilities. Learning Disabilities Research \& Practice, 30(2), 76-90. https://doi.org/10.1111/ldrp.12054

Hair, J.F., Black, W.C., Babin, B.J., Anderson, R.E., \& Tatham, R.L. (2006). Multivariate Data Analysis (6th ed.). Upper Saddle River, NJ: Pearson Education, Inc.

Hariyadi, S., Fikri, K., \& Fatahillah, A. (2016). Integrasi Nilai-nilai Kearifan Lokal pada Pembelajaran IPA Berbasis Lingkungan di Sekolah-sekolah Wilayah Perkebunan Kopi Kalibaru. Prosiding Seminar Nasional Biologi 2016. Universitas Negeri Surabaya, 1, 520-524.

Intaros, P., Inprasitha, M., \& Srisawadi, N. (2014). Students' Problem Solving Strategies in Problem Solving-mathematics Classroom. Procedia - Social and Behavioral Sciences, 116(0), 4119-4123.

https://doi.org/10.1016/j.sbspro.2014.01.901

Jitendra, A.K., Petersen-Brown, S., Lein, A.E., Zaslofsky, A.F., Kunkel, A.K., Jung, P.G. et al. (2015). Teaching mathematical word problem solving: the quality of evidence for strategy instruction priming the problem structure. Journal of Learning Disabilities, 48(1), 51-72. https://doi.org/10.1177/0022219413487408

Kemendiknas (2010). Pengembangan Pendidikan Budaya Dan Karakter Bangsa: Pedoman Sekolah (Development of Cultural Education and Nation Character: School Guidance). Jakarta: Balitbang Puskur.

Krulik, S., \& Rudnick, J.A. (1996). The new sourcebook for teacbing reasoning and problem solving in junior and high school. Boston, MA: Allyn and Bacon.

Kun, P.Z. (2013). Pembelajaran Sains Berbasis Kearifan Lokal. PROSIDING : Seminar Nasional Fisika Dan Pendidikan Fisika, 2(1), 246-256.

Laisema, S., \& Wannapiroon, P. (2014). Design of Collaborative Learning with Creative Problem-solving Process Learning Activities in a Ubiquitous Learning Environment to Develop Creative Thinking Skills. Procedia - Social and Behavioral Sciences, 116(september), 3921-3926.

https://doi.org/10.1016/j.sbspro.2014.01.867

Lin, W.L., \& Lien, Y.W. (2013). The Different Role of Working Memory in Open-Ended Versus Closed-Ended Creative Problem Solving: A Dual-Process Theory Account. Creativity Research Journal, 25(1), 85-96. https://doi.org/10.1080/10400419.2013.752249

Marcela, G.Z., \& Héctor, F.G. (2018). The Use of Educational Platforms as Teaching Resource in Mathematics. Journal of Technology and Science Education, 8(1), 63-71. https://doi.org/10.3926/jotse.337

Mungmachon, M.R. (2012). Knowledge and Local Wisdom: Community Treasure. International Journal of Humanities and Social Science, 2(13), 174-181.

OECD (2015). PISA for Development, 2013 (March), 11-13.

Parwati, N.N., Sudiarta, IG.P., \& Mariawan, I.M. (2014). Pengintegrasian Nilai Kearifan Lokal Masyarakat Bali dalam Model Pembelajaran Pemecahan Masalah Matematika untuk Membangun Karakter Positif Siswa SD Di Kabupaten Buleleng. Stranas Research Report, unpublish. Universitas Pendidikan Ganesha. 
Parwati, N.N. (2011). The effect of instructional strategies and problem types towards the problem solving ability of elementary school students with different attitudes towards mathematics. Disertasi. Universitas Negeri Malang, Malang.

Phonapichat, P., Wongwanich, S., \& Sujiva, S. (2014). An analysis of elementary school students' difficulties in mathematical problem solving. Procedia -Social and Behavioral Sciences, 116(2012), 3169-3174. https://doi.org/10.1016/j.sbspro.2014.01.728

Polya, G. (1957). How to Solve It (2nd ed.). New Jersey: Princeton University Press.

Pornpimon, C., Wallapha, A., \& Prayuth, C. (2014). Strategy Challenges the Local Wisdom Applications Sustainability in Schools. Procedia - Social and Behavioral Sciences, 112, 626-634.

https://doi.org/10.1016/j.sbspro.2014.01.1210

Reigeluth, C.M., \& Carr-Chellman, A.A. (2009). Instructional Design Theories and Models. In Instructional-Design Theories and Models (III) (199-224). Building a Common Knowledge Base.

Rokhman, F., Hum, M., Syaifudin, A., \& Yuliati. (2014). Character Education for Golden Generation 2045 (National Character Building for Indonesian Golden Years). Procedia - Social and Behavioral Sciences, 141, 1161-1165. https://doi.org/10.1016/j.sbspro.2014.05.197

Sánchez-Martín, J., Álvarez-Gragera, G.J., Davila-Acedo, M.A., \& Mellado, V. (2017). Teaching technology: From knowing to feeling enhancing emotional and content acquisition performance through Gardner's Multiple Intelligences Theory in technology and design lessons. Journal of Technology and Science Education, 7(1), 58. https://doi.org/10.3926/jotse.238

Sharif, A., \& Gisbert, M. (2015). The Impact of Culture on Instructional Design and Quality. International Journal of Instruction, 8(1), 1694-609. https://doi.org/10.12973/iji.2015.8111a

Tatar, E., Tüysüz, C., Tosun, C., \& İlhan, N. (2016). Investigation of Factors Affecting Students' Science Achievement According to Student Science Teachers. International Journal of Instruction, 9(2), 153-166. https://doi.org/10.12973/iji.2016.9211a

Tuckman, B.W. (1999). Conducting Educational Research (5th ed.). New York: Harcourt Brace College Publisher.

Yusnaeni, Corebima, A.D., Susilo, H., \& Zubaidah, S. (2017). Creative Thinking of Low Academic Student Undergoing Search Solve Create and Share Learning Integrated with Metacognitive Strategy. International Journal of Instruction, 10(2), 245-262. https://doi.org/10.12973/iji.2017.10216a

\author{
Published by OmniaScience (www.omniascience.com) \\ Journal of Technology and Science Education, 2018 (www.jotse.org)
}

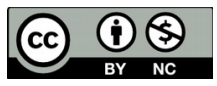

Article's contents are provided on an Attribution-Non Commercial 4.0 Creative commons International License. Readers are allowed to copy, distribute and communicate article's contents, provided the author's and JOTSE journal's names are included. It must not be used for commercial purposes. To see the complete licence contents, please visit https://creativecommons.org/licenses/by-nc/4.0/. 